\title{
The Sparrow Question: Social and Scientific Accord in Britain, 1850-1900
}

\author{
MATTHEW HOLMES \\ Centre for the History and Philosophy of Science, School of Philosophy, Religion and the \\ History of Science \\ University of Leeds \\ Leeds LS2 9JT \\ $U K$ \\ E-mail:prmrh@leeds.ac.uk
}

\begin{abstract}
During the latter-half of the nineteenth century, the utility of the house sparrow (Passer domesticus) to humankind was a contentious topic. In Britain, numerous actors from various backgrounds including natural history, acclimatisation, agriculture and economic ornithology converged on the bird, as contemporaries sought to calculate its economic cost and benefit to growers. Periodicals and newspapers provided an accessible and anonymous means of expression, through which the debate raged for over 50 years. By the end of the century, sparrows had been cast as detrimental to agriculture. Yet consensus was not achieved through new scientific methods, instruments, or changes in practice. This study instead argues that the rise and fall of scientific disciplines and movements paved the way for consensus on "the sparrow question." The decline of natural history and acclimatisation stifled a raging debate, while the rising science of economic ornithology sought to align itself with agricultural interests: the latter overwhelmingly hostile to sparrows.
\end{abstract}

Keywords: Acclimatisation, Agriculture, Economic ornithology, Natural history, Species history

In an 1892 letter to The Times, Earl Cathcart, President of the Royal Agricultural Society, announced the launch of a new field of scientific inquiry in Britain. "Economic ornithology" would examine the economic impact of birds on agriculture, a topic neglected by "recognized text-books on ornithology" which only provided readers with "vague and agriculturally useless statements" (Cathcart, 1892). To illustrate why such a science was required, Cathcart pointed to the daily influx of letters and notices on birds and agriculture which appeared in newspapers like The Times. One letter which caught his attention was an account of the activities of the Epping Sparrow Club, which claimed to have exterminated some six thousand sparrows. Without the missing 
science of economic ornithology, according to Cathcart, there appeared to be no way of telling whether or not the sparrows had been wrongfully killed under the presumption that they destroyed crops.

The house sparrow (Passer domesticus) is a ubiquitous, robust and globally adaptable bird, which has provoked feelings ranging from delight to loathing (Todd, 2012, pp. 8-9). In nineteenth-century Britain, attitudes towards the sparrow revolved around the question of whether the species was beneficial or detrimental to grower's livelihoods. For over fifty years, interested parties scrutinised the diet and behaviour of these seemingly inoffensive birds. Did sparrows consume harmful insects, thereby providing a service to agriculturalists and horticulturalists? Or did the birds primarily subsist on farmers' crops? Applicability to real-world problems acted as a litmus test for nineteenth-century science. Bellon (2011, p. 395) describes how wild speculation was abhorrent in an age where scientific praise was laden upon "painstaking", "humble" and "patient" observers, rather than theoreticians. Yet consensus on practical questions was not always reached through irrefutable experiment or careful observation. I argue that changing attitudes towards the sparrow are exemplary of wider changes in the Victorian life sciences.

For many in the humanities, animals act as barometers of human society. Anthropologists such as Roy Willis (1974, p. 7) have long stated that our attitudes towards species are revelatory of societal groups and their self-conception. The study of human-animal relationships has gone from strength to strength in recent years, in no small part due to the rise of environmental history. In this discipline and related fields, an animal, or species, has often taken centre stage as an object of historical study. ${ }^{1}$ Exploring human attitudes towards an organism uncovers contemporary social, cultural and economic interests: a methodology similar to leading environmental historian John McNeill's (2003, pp. 7-9) trinity of material, political and socio-cultural approaches to history. A species-based history consists of two idealised outcomes: an account of both historical attitudes towards the natural world and how its denizens have in turn shaped human society.

For environmental historians, linking contemporary changes in science and society to human attitudes towards the natural world has become second nature. This approach elucidates how different social

${ }^{1}$ Some recent examples from the journal Environmental History include Specht (2016) on Texas Longhorn cattle, Lee Nelson (2016) on "teredo" (marine wood-boring organisms) and Seeley and Skabelund (2015) on tigers in Korea. 
worlds and scientific disciplines have interacted with individual species. ${ }^{2}$ I therefore examine a species which encapsulates both controversy and rapport - the British house sparrow (Passer domesticus) - in the period from 1850 to 1900 . During this time, arguments over whether birds could be harnessed as a form of biological control to suppress insect pests raged in British periodicals and newspapers. Across much of this fifty-year span, sparrows were highly contentious birds, failing to produce any form of consensus. Yet by the end of the century, the argument that sparrows were detrimental to agriculture had largely won out, a trend cemented by the outbreak of the First World War.

In this paper, I uncover the history of the sparrow in late nineteenthcentury Britain and its place in four social worlds; those of the agriculturalist, natural historian, acclimatiser and economic ornithologist. I then discuss how the accessibility of natural history fuelled the sparrow debate, as diverse opinions and observations on the utility of the birds appeared in newspapers and periodicals. A growing consensus on sparrows' utility — or lack thereof - eventually emerged in tandem with the rise of economic ornithology and the decline of natural history and the acclimatisation movement. I therefore argue that the changing nature of the late nineteenth-century life sciences, rather than new discoveries or theories, allowed consensus to be reached on the sparrow question.

\section{Agriculture}

In agricultural circles, sparrows had been considered pests, or vermin, since the eighteenth century. Burgeoning numbers of the birds on agricultural land were perceived to threaten fields of ripening corn, a resulting national paranoia surrounding sparrows persisting into the late nineteenth century (Lovegrove, 2007, p. 176). ${ }^{3}$ Arable farmers and horticulturalists regularly trapped, poisoned or shot sparrows on their land or property. Local meetings of agricultural societies and so-called "sparrow clubs" uniformly condemned sparrows' consumption of crops. Once labelled as "vermin," non-productive species were freely

\footnotetext{
2 I draw upon Star and Griesmer's (1989) use of the term "social worlds" to denote a group or network of people defined by shared interests, or a common vision. These interests could be economic - as in the case of agriculturalists - or scientific. A degree of heterogeneity can exist within social worlds. Some social worlds may achieve homogeneity by throwing up barriers to entry.

3 "Corn" was a general term for cereal crops. In England, it was most often used to refer to wheat.
} 
persecuted in the fields of Victorian Britain (Lovegrove, 2007; Thomas, 1983). Traditional attitudes to wildlife management were neatly summed up by Charles Newman (1861), a British farmer who wrote to the Nottinghamshire Guardian newspaper in protest at proposed legislation for the protection of birds brought before the French senate:

No doubt many persons are opposed to their [sparrows'] destruction, considering that this feathered race were created for some wise purpose. Such was undoubtedly the case in the original order. But the Great Creator made man to rule over the fowls of the air and the beasts of the field, leaving it to his judgment to destroy such that were found more destructive than beneficial.

As a "practical farmer," Newman considered the conservation of sparrows - or as he termed them, "flying mice"—unthinkable. Contrary to narratives of increasingly enlightened attitudes towards the natural world, many rural workers still perceived animals as subject to their divinely-ordained control. Those creatures that interfered in humans' utilitarian activities could be eliminated without undue pangs of conscience. Sparrows were certainly perceived as interfering. An account of the annual meeting of the Chester Farmers' Club described the "ravages" of sparrows subsequent to the birds "invading the farmyard." (The farmers and the sparrows, 1889). ${ }^{4}$ Anthropomorphising sparrows as an attacking or invasive force reflected the economic losses incurred by growers. Sparrows were estimated by some attendees as destroying one-tenth of growers' crops, while one farmer incurred costs of one pound, seventeen shillings and nine pence (a significant sum) for the destruction of 1,835 birds of unspecified species (The farmers and the sparrows, 1889).

Newman's sparrow phobia possessed powerful social and institutional backing. Agricultural chambers, clubs and societies were regularly roused in passionate tirade against sparrows. A correspondent (who described themselves as an "observer") wrote to The Essex Standard reporting their despair that an 1867 meeting of the Coggeshall and United Parishes Agricultural Society had supported the systematic destruction of sparrows. A young John Bright, in the employ of a Mr. Catchpool, was praised by society members for destroying 650 sparrows and 195 rats (Farmers and sparrows, 1867) In 1896 a campaign against sparrows was launched by Yorkshire farmers, who denounced the bird as a "complete pest," with some members of the West Riding Chamber

${ }^{4}$ Many of the newspaper correspondents who participated in the sparrow debate remained anonymous. When this occurs, I give the title of the letter or article. 
of Agriculture claiming to verge on bankruptcy: a consequence of the bird's deprecations (Yorkshire farmers and sparrows, 1896). Numerous letters and opinion pieces in the agricultural and horticultural columns of British newspapers backed the actions of farmers' organisations. A reader of the Oxford Journal wrote to state that while they agreed with an earlier correspondent that certain birds should be preserved (in moderation) by horticulturalists, sparrows damaged farmers' crops and failed to keep down caterpillar numbers (The destruction of sparrows, 1862). In nineteenth-century Britain, attitudes towards species often depended on their perceived utility. The impression given by the rhetoric and actions of farmers' groups was that sparrows were not only useless, but downright destructive.

Despite legislation enacted to protect rare birds and outlaw the laying of poisoned grain, the government stood shoulder to shoulder with organisations such as the West Riding Chamber of Agriculture on the sparrow question. Published correspondence from the Secretary of the Board of Agriculture around 1897-following communication with the Home Office - confirmed that sparrows did not fall under the 1880 Wild Birds Protection Act. Furthermore, the Secretary announced that the balance of opinion on sparrows' agricultural utility, a "subject of controversy," weighed against the birds (Farmers and sparrows: 1897).

It would be overly-simplistic to cast all nineteenth-century farmers as wholly against the preservation of sparrows. When considering the "sparrow question," evidence for growers' hostility is certainly found in the mass extermination of birds across the British Isles. Yet not all agriculturalists were in favour of control. The Royal Agricultural Society of England and Wales published an 1862 pamphlet intended for European agricultural societies and schools, which stated that insectivorous birds consumed as much animal as vegetable matter, acting as "faithful protectors" of "cultivation in general" (De Tschudi, 1862, p. 246). The Society's journal commented that the folly of persecuting birds was demonstrated by the anti-sparrow campaign of Frederick the Great of Prussia, which resulted in fruit trees stripped of leaves by a burgeoning caterpillar population (De Tschudi, 1862, p. 239). ${ }^{5}$ A survey of the Society's publications from 1840 to 1849 reveals that only fifteen and a half percent of submitted articles came from "scientific professions," making its journal fairly representative of agriculturalists" views (Wilmot, 1990, pp. 18-19). Some years later, farmer Nunn (1897) wrote to The Times to favourably compare the good deeds of sparrows with the bad. For Nunn, the "goodness" of the birds was found in their

\footnotetext{
${ }^{5}$ On the history of the house sparrow in Germany, see Seitz (2007).
} 
consumption of troublesome insects.

Hostility towards sparrows did not only stem from within the farming community. Agriculturalists readily exchanged information and ideas beyond their social world. This interaction could take numerous forms; for instance, the correspondence exchanged between Charles Darwin and potato-grower James Torbitt during the 1870s on the distribution of blight-resistant potatoes to Irish growers (Dearce, 2008). Other actors stood more overtly on the boundary between social worlds. Self-taught entomologist Eleanor Ormerod came from a wealthy family, growing up on a large estate (Wallace, 1904). Following the demise of her autocratic father, she published numerous reports and papers on economic ornithology and later became a consultant to the Royal Agricultural Society of England in 1882 (Gates, 1998, p. 88). Ormerod weighed in on the sparrow controversy with an 1892 co-authored paper in the Journal of the Royal Horticultural Society, which drew upon the conclusions of early economic ornithologists to emphasise the damaging impact of sparrows on agriculture (Ormerod and Tegetmeier, 1897-1898).

By the close of the nineteenth century, growers had generally not warmed to the concept of sparrows as a form of biological control. Characterising this community as uniformly in favour of persecuting sparrows would miss important exceptions. Yet there is no avoiding the conclusion that much of the opposition to sparrow conservation featured agriculturalists, or at least made reference to the economic wellbeing and productivity of their community.

\section{Natural History}

For many Victorians, scientific and social life orientated itself around natural history. Definitions of what practices constituted natural history were loose, as were those practitioners who might be described as natural historians. Rehbock (1983, pp. 6-7) describes an underlying tension within nineteenth-century natural history, as "philosophical" theorists sought to distance themselves from mere collectors and observers. Yet even "philosophical natural history" lacked a firm definition: referring to an attitude toward natural history characterised by several different features (Rehbock, 1983, p. 7). Unfazed by such ambiguity, natural history enthusiasts infamously lurched between the latest collecting fads. Moving from ferns to aquariums, devotees stripped specimens from the countryside in alarming numbers (Allen, 1996, pp. 404-405). 
Inexpensive guides poured off the presses, making collecting popular, if not ubiquitous (Dunlap, 1999, p. 28). Nineteenth-century naturalists of all stripes were driven by an overarching sense of purpose, or participation in a grand intellectual endeavour. Acquiring and systematising knowledge gleaned from study of the natural world was associated with moral, religious and social wellbeing.

All societies have anthropomorphised aspects of their environment, including animals. Yet Victorian authors and naturalists took this tendency to new heights. Birds had long been considered a worthy object of study based on their suitable moral traits, including reassuring family relationships (Thomas, 1983, p. 63). Human characteristics or object lessons were readily attached to sparrows. In 1885 one newspaper declared that sparrow enthusiasts were those benevolent persons who read literature from the Animals Friend Society and believed sparrows to be "the feathered friend of man" (Sparrows and the crops, 1885). An article in the Rural World magazine invoked sympathetic metaphors in its natural historical account of the house sparrow. Its author compared the reckless audacity and impudence of the bird to the average British boy (The ubiquitous sparrow, 1889). Unemployed rural labourers who killed birds such as sparrows, linnets and finches were said to deploy instruments of "revenge and malignity" in their work, namely poisons such as arsenic, strychnine and phosphorous (Destruction of small birds, 1862). While popular, some consider the moral authority drawn from natural history to have proved detrimental to the field's survival. In the early years of the twentieth century, an idealised form of natural history found an audience among the expanding middle class, who cultured their rustic vision in expanding suburbs (Broks, 1996, pp. 7980). The introduction of "nature study" to British classrooms also led to the association of natural history with schools and juvenilia (Allen, 1998, p. 367). ${ }^{6}$

By the nineteenth century, nature was understood as part of a created order, existing in a form of equilibrium, which could be upset by rash human action. One newspaper report strongly recommended maintaining a balance between the "feathered tribe" and agriculture (The sparrow club, 1855). A decade later, Donald George Forbes MacDonald (1865), known for his writing on farming and estate management, referred to sparrow eradication as interference in the "Divine organisation of nature." Religious and moral connotations were drawn when this balance was upset through capriciousness or

${ }^{6}$ Nyhart (1996) provides a critical take on histories of biology which emphasise the decline of natural history and rise of "modern" biology. 
carelessness. A letter to The Quarterly Journal of Agriculture told the tale of a horticulturalist who had exterminated sparrows in his fruit orchard with the use of poisoned wheat, only to suffer "myriads of caterpillars, green and black-marked ugly things," which stripped whole bushes of their leaves. To add to the "poetical justice" suffered by the thoughtless grower, birds that did not eat the poisoned wheat, including chaffinches and thrushes, also "despoiled the trees of their fruit" (Destruction of sparrows, 1841).

By the late nineteenth century, ideas of "living communities," or many of the qualities of what is now termed ecology, were found in German universities, represented by such figures as Ernst Haeckel and Karl August Möbius (Nyhart, 2009, p. 2). Yet ideas of a natural balance, or "economy" within nature, far predated their scientific codification, as demonstrated by Worster (1985). In natural history, the balance of nature was a vague, albeit popular, understanding of plant and animal populations. Allen (1998, p. 367) described British ecology as "another light that failed," as ecologists adopted a physiological approach which pushed the discipline out of the reach of naturalists by the turn of the century (Allen, 1998, p. 367). Instead, British naturalists and rural workers were informed by tacit knowledge, gleaned from wildlife management and observation in gardens, fields and cities. Occasionally, a combination of moral sentiment, religious leanings and sense of balance in nature led some to declare sparrows an unmitigated blessing to agriculturalists, worthy of conservation and encouragement from both growers and the political establishment (Sparrows and the crops, 1885).

Natural history represented a shared culture or civic project (Barber, 1980; Finnegan, 2005). Yet not all those who drew upon natural history were convinced by the agricultural utility of sparrows. Newman, who angrily affirmed the dominion of agriculturalists over wild species, was no stranger to natural history. In his 1861 tirade against sparrow conservation, Newman drew upon the first volume of English naturalist Oliver Goldsmith's History of the Earth (originally published in 1774) to demonstrate that crop-eating caterpillars were destroyed by rain, making the role of sparrows in their control of no significance (Newman, 1861; Goldsmith, 1816, pp. 61-62). Industrialist and ornithologist Henry Seebohm's A History of British Birds (1883) contained testimony demonstrating that farmers in the north of England had ceased growing corn due to the inroads of sparrows (The increase and destructiveness of sparrows, 1884). A study on sparrows' diet carried out by a Lieut. Russell (1883) appeared in the journal of the Essex Field Club and 
reported similar findings. Russell (1883, p. 22) examined the stomachs of thousands of sparrows at different times of the year, arriving at the conclusion that ninety-five percent of the birds' diet consisted of corn.

Just as it would be a mistake to cast nineteenth-century agriculturalists in a monolithic block, the same lesson applies to natural historians. Its practitioners only represented a coherent community in the sense that many engaged in observation and collection, while attaching great spiritual and social significance to their findings. This did not always imply agreement. Meaningful attempts were made to add greater value to private observations, through detailed record-keeping or sheer quantities of information gathered. An 1868 article in the Glasgow Herald attempted to quantify the volume of cockchafers - a type of beetle - devoured by sparrows. Its author counted empty wing cases found below a sparrow nest, ultimately estimating that a single pair of sparrows could devour fourteen thousand beetles to feed their young (Another plea for sparrows, 1868). Almost three decades later, a Cumberland parson recited the results of his "careful observation" of sparrows in his vicarage garden over a period of seventeen years (The poor sparrows, 1895). Yet results were often ambiguous or perceived as tainted by personal biases. Hence an 1884 newspaper report on sparrows remarked that to resolve the question of the birds' utility, old prejudices would have to be laid aside and "more systematic observations," including dissections, carried out (The increase and destructiveness of sparrows, 1884).

\section{Acclimatisation}

Information on the utility of sparrows in agriculture was not confined to British shores. From the mid-nineteenth century, the movement of avian species around the globe was encouraged by various acclimatisation societies, which sought to improve national diet and economic productivity through the introduction of plants and animals (Barber, 1980, pp. 147-149; Anderson, 1992, p. 135). These societies claimed interested naturalists and landowners among their members, who encouraged the import of exotic species. In 1865 the Acclimatisation Society of Great Britain merged with the Ornithological Society of London, overseeing the introduction of numerous game birds, from Japanese pheasants to California quails (Lever, 1992, p. 82). Acclimatisation societies were also founded abroad, encouraged and assisted by their European counterparts, with the aim of improving the biotic quality and content 
of new lands. Upon their arrival in newly-conquered territory, European colonisers often perceived the fauna and flora of their new surroundings to be deficient, even hostile. By 1900, in excess of fifty acclimatisation societies had formed, mostly in European colonies. Species were imported for a variety of reasons, ranging from nostalgia to scientific curiosity (Lever, 1992, pp. 193-194; Osborne, 2000, p. 136). English sparrows found themselves transported to the United States, Canada, Australia and New Zealand. Many of the societies unloaded sparrows to fulfil a sense of nostalgia or aesthetic pleasure, with little evidence of scientific orientation (Lever, 1992, p. 190). In the wider context, acclimatisation movements fell outside the remit of European scientific and administrative elites, their "amateur" leanings and repeated failures perhaps accounting for their ephemeral nature (Osborne, 2000, p. 151).

Initial success in the acclimatisation of the sparrow in Australia was repeatedly drawn upon by both sides of the debate, even as the reputation of the bird on that continent rapidly waned following its initial success in controlling insect pests. Once established on the Australian continent, acclimatisation societies moved to rejuvenate their local biota, in the process introducing foxes, rabbits and the prickly pear, with unfortunate consequences for growers (Osborne, 2000, p. 141). These societies met with popular apathy or hostility, as their members were seen to act in the interests of privileged elites, a belief confirmed by societies' introductions of British songbirds and "animals of the chase" (Lever, 1992, p. 100). Yet insectivorous birds such as sparrows could potentially be deployed in defence of settler agriculture, regardless of controversy over their utility in their home countries. Resulting increases in agricultural or horticultural yields would act as a credit to acclimatisation societies. In 1863 the Acclimatisation Society of Victoria (based in Melbourne) incubated imported house sparrow eggs, before introducing the fledglings to Murrurundi in 1865 (Lever, 1992, p. 104). British newspaper correspondents began citing the ongoing experiment of English sparrows in Australia from the 1860s. An observer wrote to the editor of The Essex Standard in 1867 to remark that Australians and New Zealanders had gone to great lengths to import house sparrows, so convinced they were of the utility of sparrows "to the farmer, gardener, and seed grower, by the destruction of insects [sic]." In stark contrast, he noted that British growers sought to destroy the birds at every turn (Farmers and sparrows, 1867).

Reflecting this dichotomy, an Australian with interests in acclimatisation remarked that the prospering of introduced sparrows in his country 
since 1862 had provoked the "same kind of controversy that has long raged in other countries" (The troubles of our friends in Australia, 1868). With sparrows turning upon fruit gardens, the correspondent was asked by a "society" to gather "authentic information, as to the balance of his [the sparrow's] merits and demerits." His mention of a society was presumably a reference to an Australian acclimatisation society. Both the Australian acclimatiser and the British newspaper that carried his report favoured the merits of sparrows. Yet the Australian love for the sparrow proved a short-lived affair, a fact quickly seized upon by detractors of sparrows' utility. The same correspondent stated that Australian settlers had introduced sparrows to combat homesickness, but would soon need their own sparrow clubs in Victoria to control the birds (The troubles of our friends in Australia, 1868). A decade later The Derby Mercury charted the rapid reversal of Australian opinion:

For ten or fifteen years, perhaps, the Australian gardeners and farmers and the sparrows got on exceedingly well together. The busy little birds faithfully performed all that was expected of them, and the land was well nigh rid of grub and caterpillar. Presently, however, there gradually arose a feeling of uneasiness as to the increase and multiplication of the imported blessing (A plague of sparrows, 1878).

Sparrows turned upon crops in the absence of insects. Soon enough, poison, sparrow shooting clubs and even the domestic cat were deployed as "The poor bird's adopted country begrudges him even the nest he dwells in" (A plague of sparrows, 1878). By the end of the nineteenth century, persecution of Australian sparrows had not subsided. The sparrow question engaged Britons across the globe. A Captain Becher (1885, p. 259), stationed in Karachi, thought it worth writing to The Zoologist - a monthly natural history periodical- to report that local sparrows helpfully devoured swarming red ants.

An almost identical situation to that encountered in Australia emerged in North America, resulting in the so-called "Sparrow Wars" of the 1870s. American dislike of sparrows was picked up by The Times, which related the remarkable expansion of the sparrow population in New York from only a few breeding pairs, first introduced to Union Square Park in 1866. In one year, the birds had spread forty miles in every direction and numbered over six hundred, leading an American newspaper to ask whether worm or bird represented "the greatest evil" (The English sparrow, 1868). ${ }^{7}$ An 1889 Times article was dismissive of

7 Attracted to "kernels of grain in empty boxcars," sparrows expanded across the United States via the rail network (Coates, 2006, p. 28). 
American claims of sparrows destroying grain, defiling buildings, failing to eat insects and harming native birds, noting that a large blizzard in 1888 had reduced sparrow numbers to the benefit of grubs and caterpillars (The sparrow in the United States, 1889). Elsewhere in North America, the birds were not so maligned. An English dairy school wrote to The York Herald in 1884, citing the favourable reception and practical utility granted to insectivorous birds by the Ontario Agricultural Commission. Yet the evidence presented by the Canadian Commission was deemed insufficient by the school. Both "scientific observers" and agriculturalists confirmed the grievous destruction of ripened corn by "legions of sparrows" in the English countryside, including Cheshire, Lincolnshire and Yorkshire (Sparrows and corn, 1884). Exotic accounts of acclimatisation and insect control in the imperial context did not necessarily overrule the observations and practical knowledge of local naturalists and growers.

Acclimatisation, agriculture and natural history often acted as allied movements. Like natural history, acclimatisation represented a community with a broad social and economic remit, which counted numerous naturalists among its ranks. A form of improvement project, acclimatisers' practitioners and their international networks of plant and animal exchange bore a strong resemblance to those of natural history. Anderson (1992, p. 147) notes that the British acclimatisation movement relied upon "gentlemen plant and animal breeders [who] supported agricultural experimentation." Naturalists such as Owen and Buckland were active supporters and participants in the acclimatisation movement. Others, including Charles Darwin and Alfred Russel Wallace, also endorsed acclimatisation projects and drew upon the findings of acclimatisers for their own research (Anderson, 1992, pp. 150-151). Despite its promise, the acclimatisation movement faltered by the end of the century, while the damaging presence of sparrows in new lands only added more ammunition to their detractors (Anderson, 1992, p. 152; Osborne, 2000, p. 146).

\section{Economic Ornithology}

In 1892 the term "economic ornithology" appeared in a letter to The Times written by Earl Cathcart, then-president of the Royal Agricultural Society. Cathcart (1892) defined economic ornithology as "the study of the inter-relation of birds and agriculture," stating that the promising field lay open for investigation by English agricultural sci- 
entists. A call for agricultural scientists to study birds was indicative of both Cathcart's agrarian interests and the ongoing sparrow debates. Cathcart's communication with "the headquarters of English ornithology" had proved discouraging on the subject of economic ornithology, leading him to urge agricultural scientists and "scientific ornithologists" to provide practical information to agriculturalists. Yet some who answered Cathcart's call were clearly biased, such as naturalist William Bernhard Tegetmeier who produced the colourfully titled and favourably reviewed The House Sparrow (The Avian Rat): In Relation to Agriculture and Gardening, with Practical Suggestions for Lessening its Numbers (1899). An anonymous reviewer (The house sparrow, 1899) in The Zoologist agreed with Tegetmeier's assessment of the sparrow as a "pestilent marauder," appealing to evidence from both ornithological authorities and experienced farmers and horticulturalists. A consummate journalist, Tegetmeier firmly established himself on one side of the sparrow debate (Richardson, 1916). Other writers were more cautious, taking steps to incorporate both sides of the sparrow argument into their studies on economic ornithology.

Formative influences on British economic ornithology included earlier works of natural history, controversy in the press and the experiences of acclimatisers and ornithologists abroad. These influences were illustrated in a short tract on the diet of the house sparrow by ornithologist Gurney (1885). In the preface of his work, Gurney acknowledged the "great public interest" surrounding the depredations of sparrows in England, the Colonies and America, before engaging the claims made in naturalist William Yarrell's A History of British Birds (1843, pp. 474-478). To advance the debate surrounding birds in agriculture in as balanced and unpolemical a manner as possible, Gurney's work contained sections by experts that he hoped would placate both sparrow lovers and haters. A familiar name was that of Colonel C. Russell — cast as "a friend of the farmer"-who fulfilled his prescribed role by continuing to maintain that humankind would do as well without sparrows as without rats or cockroaches (Russell, 1885). When self-described economic ornithological studies first emerged in Britain, the imprint of nearly fifty years of debate was evident. Gurney (1885, p. 1) remarked that the "sparrow question" was clearly an important one, even if only a fraction of what was related by "farmers' clubs and agricultural newspapers" turned out to be true.

Despite a rash of new studies in economic ornithology from the late nineteenth century, British enthusiasts of the science confessed to lagging behind their American counterparts. Cathcart's (1892) letter to The 
Times remarked that Britons were "far behind our cousins in the United States," whose Agricultural Department had been producing valuable and practical information on birds for growers since 1885. American expertise was recognised by Gurney, whose tract included a reproduced section from The English Sparrow in America (1867), authored by prominent American ornithologist, Dr. Elliot Coues (1885). ${ }^{8}$ While many Americans had turned against sparrows during the "Sparrow Wars" of the 1860s and 1870s, economic ornithology in the United States enjoyed greater prestige and institutional support than its British counterpart. Coates (2006, p. 59) describes how "interested British parties" followed American developments, with an 1879 report to the Federal government made by Coues "in considerable demand."

In Britain, there was significant public debate about economic ornithology. In 1895 Gurney presented a paper on the destructiveness of sparrows at the Norfolk Chamber of Agriculture. Yet new science did not equate to new attitudes. To cries of "hear, hear," Gurney informed the Chamber that the day when sparrows would be placed in the same category of stinging-nettles and wasps was not far off (Sparrows and agricultural crops, 1885). Dissections of nearly eight hundred birds had confirmed Russell's findings that the diet of adult sparrows consisted of approximately seventy-five percent corn. This revelation neatly coincided with the opinion of American economic ornithologists, who considered the sparrow to largely consume corn, not insects. Yet Gurney did introduce one caveat to the Chamber:

In conclusion he [Gurney] observed that the sparrow did more harm than good under ordinary circumstances was proved; but it was not clear that in the case of the exceptional abundance of some noxious insect or some noxious weed it might not be of great service. If the balance of nature was upset by exterminating sparrows we might have to pay an unknown penalty; and with this in view it might be wise for the Norfolk Chamber of Agriculture to recommend their being kept in bounds, but never that they should be entirely exterminated (Sparrows and agricultural crops, 1885).

In the late 1890s, Tegetmeier collaborated with entomologist Eleanor Ormerod (consultant to the Royal Agricultural Society of England) to produce a review of recent studies on the "sparrow question," with the

8 A former military surgeon, Coues entered the American "Sparrow Wars" in 1874, engaging in an increasingly bitter debate with physician, journalist and ornithologist Thomas Mayo Brewer. In 1880, Brewer, "the only reputable [American] ornithologist to befriend the sparrow" died, leaving Coues to continue his attack upon the birds (Brodhead, 1971, pp. 428-429). 
intention of bringing research to both "those practically concerned" and the wider public (Ormerod and Tegetmeier, 1897-1898, p. 413). Russell's meticulous dissections were singled out for praise, not least because his work had attracted the attention of both the British Wild Birds Parliamentary Committee and the Department of Agriculture in the United States (Ormerod and Tegetmeier, 1897-1898, p. 417). To dispel any doubts or accusations of fraud, Ormerod and Tegetmeier (18971897, p. 418) reported that Russell's "contents of sparrows" had been preserved in glass jars, which clearly contained an "enormous proportion of wheat grains." The opinions of both American and British economic ornithologists had aligned against the sparrow.

Economic biologist Collinge (1913, p. 1) would later state that "casual observations made in the field" had often been invoked in newspaper discussions on economic ornithology, but were either deficient in scientific value or actively misleading. As such, economic ornithology struggled to establish itself as an independent scientific discipline in Britain. There was little or no sign of institutional formation or training. Instead, self-professed contributors to British economic ornithology such as Gurney and Russell emerged from backgrounds in natural history or agriculture. In the years prior to 1914, there does seem to have been a temporary flourishing of scientific writings on economic ornithology, including Collinge's own textbook, The Food of Some British Wild Birds (1913). Under wartime conditions, established practices of species control were again adhered to in agriculture. Sparrows were portrayed as pests, subject to popular campaigns of extermination.

At the anniversary dinner of the Cricklade Sparrow Club in 1855, two members proudly produced the result of that year's efforts; the grisly remains of 5812 sparrows (Wholesale destruction of sparrows, 1855). Sparrows were contested animals, loved and despised in equal measure. Yet as the "sparrow question" was debated in meetings, newspaper columns and journal articles, persecution of the species continued unabated. By the end of the nineteenth century, it was clear that the opinions of growers and economic ornithologists had largely converged on the detrimental effect of sparrows to agriculture.

\section{Accessibility and Non-consensus}

Why did the British sparrow debates rage for so long and with such ferocity? To answer this question, I argue that close attention should be paid to the changing nature of the Victorian life sciences. Natural his- 
tory was an inclusive enterprise, allowing a plethora of diverse voices to weigh in on the sparrow question. Exchange of information and ideas between warring social worlds was greatly facilitated by the accessibility of natural history. Periodicals and newspapers provided a platform for farmers and naturalists to present their opinions, free of supervision or patronage. Agreement could not easily be reached when almost anyone could speak with authority - often drawing upon their own observations or anecdotes - on the sparrow question. Constraints on who could speak with scientific authority on the sparrow were therefore required for consensus to emerge. The decline of natural history in Britain towards the end of the nineteenth century, a trend paralleled by the rise of economic ornithology, provided such constraints. ${ }^{9}$

During the sparrow debates, economic ornithologists and naturalists such as Ormerod, Russell and Gurney were able to simultaneously appeal to commercial and scientific communities. All three moved between social worlds, writing for natural history periodicals, engaging with ornithological textbooks and addressing agricultural organisations. Yet an equally influential means of translation was British newspaper columns. Here, letters were exchanged daily, between both prominent scientific figures and anonymous farmers and gardeners. Disagreement and hostility were rife, but slowly resulted in a form of consensus over how the sparrow question should be addressed.

In 1884 The Ipswich Journal remarked that to resolve the sparrow debate, traditional prejudices would have to be laid aside and "more systematic observations," including dissections, carried out (The increase and destructiveness of sparrows, 1884). The Western Mail supported this programme, directing its readers towards early studies in economic ornithology (Sparrows and the crops, 1885). Systematic investigations could apparently provide an indisputable source of objective evidence, to finally solve the question of birds' utility to the British grower. A successful model was provided by late nineteenthcentury investigations in the United States, which involved hundreds of studies on the role of birds in agriculture (Evenden, 1995, p. 173). Calls for new approaches represent a form of what Star and Griesemer (1989, pp. 392-393) termed "method standardisation." Yet standardisation alone did not create consensus. Neither quantitative studies, such as that described in the 1868 Glasgow Herald (Another plea for sparrows,

\footnotetext{
${ }^{9}$ Changes to sparrow behaviour or numbers cannot explain why the sparrow debates eventually died down. Despite the activities of organisations such as the Cricklade Sparrow Club, the British sparrow population seemed largely unabashed by the fevered arguments which seethed around it. Lovegrove (2007, pp. 177-179) estimates that the sparrow population in Britain remained largely stable until the late twentieth century.
} 
1868), nor the mass dissections later carried out by Russell and Gurney generated immediate agreement.

Scientific practices such as dissection and quantification may not have been held in universal esteem. Yet across interested communities, some theories and methodologies were held in common. Natural history was utilised by agriculturalists, while naturalists participated in the activities of acclimatisation societies and economic ornithology. As Barber (1980, p. 28) stated, until the 1860s, "the naturalist might be anyone from Darwin down to the lowliest Sunday bug-hunter." As anyone who practiced natural history could be classed as a naturalist, even a lowly bug-hunter could find acceptance across social and scientific boundaries. While easy access to natural history acted as an effective translator across communities, this allowed for a great deal of variable opinion from a large number of actors.

Such was the ubiquity and civic virtue attached to natural history that naturalists appeared across and within all four social worlds involved with sparrows during the nineteenth century. Just as moral lessons were attached to nature, so the practice of natural history was thought to promote morality and civic duty. In Victorian Scotland, the rhetoric of natural history societies and field clubs portrayed the provincial naturalist as both a votary of nature and servant of civic society (Finnegan, 2005, p. 55). Fieldwork represented a blend of enlightenment, romantic and theological values, although the scientific outcome of such activity was perhaps less important than its practice (Barber, 1980, p. 21; Camerini, 1996, p. 44). Although naturalists were able to successfully collaborate, consensus on important questions was not readily reached.

Natural history represented a plethora of interests, involving investigation of the animal, vegetable and mineral kingdoms. Participants with differing degrees of interest in theory, collection or classification, participated in country or seaside trips. One explanation for the accessibility of natural history is found in its appeal to common-sense categorisation of nature, termed "folktaxonomy" or "folkbiology" (Atran, 1990, p. 21; Dunlap, 1999, pp. 22-24). While a flood of exotic specimens into the Western world overwhelmed traditional categories, these at least gave naturalists a renewed purpose, based on an enlightenment faith in human ability to comprehend nature. Other, more mundane, explanations for the widespread popularity and acceptance of natural history include the perpetual boredom of affluent Victorian families (Barber, 1980, p. 19). Regardless of the reasoning behind its appeal, natural historical work represented a powerful scientific and 
social force in nineteenth-century Britain. It is therefore unsurprising to find its methods applied to the sparrow question by actors in multiple social worlds. This ubiquity and accessibility may have facilitated communication across disciplinary and social boundaries, but made consensus problematic.

Perhaps the most indicative moment of accessibility equating to nonconsensus occurred in 1873, during the proceedings of a House of Commons Committee on the protection of wild birds. ${ }^{10}$ Witnesses from a bewildering array of backgrounds and professions were questioned, with many voicing their opinion upon the sparrow. Cambridge Professor of Zoology Alfred Newton was dismissive of the quality of the witnesses called by the Committee: "ornithologists, pseudo-ornithologists, farmers, gardeners, bird-catchers, and others" (Cowles, 2013, p. 712). As Thomas Huxley had warned Joseph Hooker in 1859, a "far lower order of men" could claim to be naturalists than in mathematics or chemistry (Bellon, 2001, p. 71). Cathcart (1892) later commented upon the diversity of "experts" called by the Committee in his version of the proceedings:

The Common's Committee took evidence of thirty-eight experts, ranging from the learned Rector of Nunburnholme, in Yorkshire, Mr. Morris, and Professor [Alfred] Newton, the Professor of Zoology at Cambridge University, down to the cockney birdcatcher who hailed from Seven Dials. Men of science, farmers, market gardeners, including amongst others, real-out-of-door naturalists, pure and simple lovers of science, a barber, a bookseller, a picture dealer, a hair-dresser, and other trades-men. Yet, on the question of the criminality or otherwise of the sparrow there was upon evidence a very evenly balanced conflict of opinion.

The accessibility of natural history was combined with the accessibility of the Victorian newspaper and periodical to give rise to a plethora of public opinions on the question of sparrows' utility in agriculture. Farmers like Charles Newman could publicly voice their disdain for bird conservation, while citing eighteenth-century natural history studies (Newman, 1861). Yet other farmers, such as Joseph Nunn (1897) found in newspapers a platform to describe their favourable observations of sparrows consuming insects. Eleanor Ormerod could draw upon her expertise in entomology to denounce sparrows to agriculturalists and horticulturalists (Ormerod and Tegetmeier, 1897-1998). Yet

${ }^{10}$ Report from the Select Committee on Wild Birds Protection; together with the proceedings of the committee, minutes of evidence, and appendix, PP, 1873, 338. 
at the same time, a Cumberland parson could draw upon his seventeen years of sparrow observation to support the birds' utility to growers (The poor sparrows, 1895). Accessibility to the sparrow debate came at a cost, as numerous and variable opinions failed to create widespread consensus until the close of the nineteenth century.

\section{Decline and Consensus}

The decline of natural history and rise of biology during the late nineteenth century constitute a historiographic backbone for established narratives on the history of the life sciences (Caron, 1988; Allen, 1998). ${ }^{11}$ Historians of science have charted the gradual division of the life sciences into a host of separate disciplines. Outram (1996, pp. 249250) situates the origin of this movement in the early nineteenth century, as separate sub-disciplines of physiology and palaeontology emerged, alongside the foundation of state-funded and controlled institutions. Di Gregorio (2009, pp. 205-206) describes how "professional" practitioners of the life sciences increasingly based themselves in museums and universities. Similarly, Johnson (2012, p. 47) noted a change in the "criteria by which expert status was conferred" in the nineteenth-century life sciences, as figures such as Thomas Henry Huxley and Richard Owen sought "to wrest control of science away from traditional title and fortune." Can the waning popularity and growing consensus on the sparrow debate therefore be explained through the death of natural history and "professionalisation" of Victorian science?

There are compelling reasons to accept that the decline of natural history in the twilight years of the nineteenth century played some role in the simultaneous decline of the sparrow debate. Newton (1899, p. 21) noted that, proportionally speaking, general works on ornithology were being supplanted by specialised monographs. Traditionally, popular works of natural history were often of a light-hearted or anecdotal nature (Allen, 1976, pp. 78-79; Barber, 1980, p. 19). Yet by the late nineteenth century these works stoked the ire of those who followed in the wake of Darwin. This lesson was cruelly learnt by the Duke of Argyll when his book The Unity of Nature (1884) was reviewed in $\mathrm{Na}$ ture by Darwinist and self-proclaimed comparative psychologist George John Romanes:

${ }^{11}$ For a succinct overview of this literature, see Strasser (2010, pp. 149-151). 
This book is in our judgement a dreary failure. Although in the mere matter of style it is a well written popular exposition of what we may call the comfortable way of looking at things, in all matters of deeper importance it is utterly barren. Throughout its five or six hundred pages there is no single observation in science, nor any single thought in anything that deserves to be called philosophy (Romanes, 1884, p. 474).

Romanes (1884, p. 474) found the book's accessible style "tedious" and criticised the Duke for describing "elementary science" in a "redundant manner." At an earlier time, a descriptive and morally-uplifting piece may have brought its author plaudits. Yet with the decline of natural history, a common moral purpose based upon accessible fieldwork was no more. Science had been stripped of its metaphysical trappings (Nyhart, 2009, pp. 15-16). In such a climate, it was unlikely that moralising farmers like Newman could quote eighteenth-century natural history texts and expect to be taken seriously. Although natural history remained popular among the general public, it experienced what Farber (2000, p. 98) termed "a scholarly decline" in the academic world of universities and research institutes. The "naturalist tradition" had been "sidelined from the most prestigious realms of the life sciences" (Johnson, 2012, p. 304).

Yet Romanes's critical review did not go completely unchallenged. The Duke of Argyll wrote to Nature to complain that Romanes's unpleasant criticism was the result of personal animosity, stemming from an earlier dispute between the pair (Argyll, 1884, p. 524). The Duke had taken issue with Romanes using the pages of Nature as a platform for his "personal beliefs, and disbeliefs, on subjects which lie outside the boundaries of physical science" (Argyll, 1884, p. 524). This response suggests that the decline of natural history was not a straightforward process. Our understanding of what happened to natural history at the end of the nineteenth century has become more complex, as it has become clear that naturalists merged with, or resisted, would-be reformers (Nyhart, 1996). The sparrow debate was part of this complex picture: natural history was not simply replaced by economic ornithology. Yet as natural history lost some of intellectual prestige, so the opportunity emerged for Cathcart and his new science of economic ornithology to intervene in the sparrow debate.

Contemporary to the decline of natural history was the collapse of the acclimatisation project, in the face of repeated practical failures (Osborne, 2000: 151). Newspaper reports on the activities of acclimatisation societies had provided another accessible source of field 
observations on the impact of sparrows on agriculture. By 1860, acclimatisation repeatedly appeared in the British news, supported by luminaries such as Richard Owen and Frank Buckland. Yet its amateurish aspects and overly-utilitarian goals ensured the project gained only a tenuous following among professional zoologists (Osborne, 2000, p. 146). Ritvo (2012, p. 405) characterises the movement as an extension of the game parks and menageries held by the wealthy and powerful: a makeup hardly endearing to a growing opposition against "traditional title and fortune" (Johnson, 2012, p. 47).

These changes lend support to Broks' (1996) and Allen's (1998) declarations of the decline of natural history as part of a wider revolution in biology. Yet the transition from natural history to separate biological disciplines did not occur overnight, or even in a coherent fashion. Nyhart (1996, pp. 439-441) charts the division of natural history into numerous sub-disciplines to account for the apparent decline of the field by 1900. Did disciplinary formation, institutionalisation and "professionalisation" provide answers to the sparrow question? Not in the case of ornithology. In 1858 an assembly of ornithologists led by Alfred Newton met in Cambridge, creating an Ornithological Union with The Ibis as its official publication (Bircham, 2007, pp. 189-190). ${ }^{12}$ Yet organisation of ornithologists did not translate into practical advances in the field. ${ }^{13}$ One essential piece of the jigsaw - ethology, or the study of animal behaviour under natural conditions - was absent. The term ethology only appeared in its modern context in 1902, with several decades passing before the large ethological congresses of the 1950s and 1960s were held (Burkhardt, 2005, p. 3-4). As late as 1896, a reviewer in Nature saw ornithology as falling under the familiar remit of natural history:

The issue of works on ornithology continues in an unbroken stream. There can be little doubt that since the arrangement of the birds in the National Museum in South Kensington, in their natural attitudes and surroundings, was adopted - a system largely followed in many of our provincial museums - there has been a distinct interest taken in natural history (Bowdler Sharpe, 1896).

\footnotetext{
12 This meeting marked the origin of the British Ornithologists' Union (B.O.U), which still operates today.

13 When ornithologists did enter the sparrow debate, their opinion was not always welcome. The United States' first ornithological society, the Nuttall Ornithological Club, was savaged in the local press following an 1878 meeting condemning the sparrow (Barrow Jr, Barrow, 1998, pp. 49-50).
} 
Aided by the input of American specialists, British economic ornithologists did provide compelling arguments against the agricultural utility of sparrows. Yet their story was not one of traditional "professionalisation." Cathcart (1892, p. 326) was keen to see the establishment of a "small school of Economic Ornithology," with candidates recruited from agricultural colleges. Yet his ideal specialist produced by such a school would be an "unselfish," yet financially independent figure like Ormerod, or product of the School of Agricultural Chemistry Sir John Lawes (Cathcart, 1892, p. 326). ${ }^{14}$ Perhaps in part due to this social makeup, the findings of economic ornithology's practitioners on sparrows quickly accorded with the concerns and opinions of broad sections of the agricultural community. Consensus between scientific thought and growers' opinion on the sparrow had been reached.

\section{Conclusions}

Aspects of the natural world have always served as a template or foil for human society. The emergence of a consensus on the detriment of sparrows to agriculture reflects changes in the British life sciences in the late nineteenth century. For over half a century, sustained debate occurred on the sparrow question. Yet multiple actors failed to agree upon a single representation of nature. This state of affairs only began to change as the nineteenth century wore on. In tandem with the decline of natural history and acclimatisation, interest and controversy over sparrows began to wane. Simultaneously, rising sub-disciplines in the life sciences such as economic ornithology appeared. Although this movement was not made up of "professional" scientists in the modern sense, it was exclusionary to those lacking patronage or an established reputation (Bellon, 2001, p. 53). Yet these communities did display greater internal coherence and hence, the ability to achieve consensus with other like-minded social worlds.

Natural history, with its lofty, albeit not necessarily coherent, ideals of rationality, romanticism and theology, had acted as a common denominator in the nineteenth-century life sciences. Seeking to classify and understand the natural world in its entirety, its varied practitioners justified their communal fieldwork with reference to moral and civic

14 Cathcart's view of what constituted the ideal expert or professional is markedly similar to that described by Bellon's (2001, p. 58) account of botanist Joseph Hooker's conception of the scientific professional: principled, reputable, social and "gentlemanly in mind \& person". 
virtue alongside utility. Despite a shared theoretical justification and standard practices of field observation, the subjective and popular aspects of natural history resulted in a sustained debate over the utility of sparrows. Yet by the end of the century, natural history was in decline, while acclimatisers were dogged by repeated failures. Economic ornithologists appeared to largely side with agriculturalists, recommending the control of sparrow populations in order to protect crops. This consensus has important implications for narratives of progressive and increasingly humanitarian approaches to wild nature (ferae naturae) from the nineteenth century (Thomas, 1983; Ritvo, 1987; Coates, 1998).

Perhaps unsurprisingly, the long-standing social world inhabited by agriculturists, which had largely consisted of an almost unrelenting barrage of hostility towards sparrows, proved most resilient. The existing opinions of this community were lent further backing by economic ornithologists. As a consequence, the First World War saw sparrows persecuted as an agricultural pest on a systematic level (Sheail, 1976, p. 122; Horn, 1984, pp. 47-48). Yet by the middle of the twentieth century, huge flocks of sparrows remained a common sight in British fields. Despite three hundred years of destruction, sparrow populations declined only during the 1990s (Lovegrove, 2007, pp. 177-179). Sparrows, the objects of study and controversy for more than 50 years, proved more resilient than many of the disciplines which sought to understand, support or persecute them.

\section{Acknowledgements}

I would like to thank my supervisors, Professor Greg Radick and Dr. Tina Barsby, for their support and feedback. An earlier version of this paper was presented at the 2015 British Society for the History of Science Postgraduate Conference at University College London: the following discussion was very encouraging. I am also grateful to the anonymous reviewers, whose comments greatly improved this article.

\section{Open Access}

This article is distributed under the terms of the Creative Commons Attribution 4.0 International License (http://creativecommons.org/licenses/by/4.0/), which permits unrestricted use, distribution, and reproduction in any medium, provided you give appropriate credit to 
the original author(s) and the source, provide a link to the Creative Commons license, and indicate if changes were made.

\section{References}

\section{Archival Sources}

House of Commons Parliamentary Papers; referred to as PP.

\section{Published Sources}

"A plague of sparrows." 1878. The Derby Mercury, 05 June.

Allen, D. E. 1976. The Naturalist in Britain: A Social History. Harmondsworth: Penguin.

— 1996. "Tastes and Crazes." N. Jardine, J. A. Secord and E. C. Spary (eds.), Cultures of Natural History. Cambridge: Cambridge University Press, pp. 394-407. 1998. "On parallel lines: natural history and biology from the late Victorian period." Archives of Natural History 25: 361-371.

Anderson, W. 1992. "Climates of Opinion: Acclimatization in Nineteenth-Century France and England." Victorian Studies 35: 135-157.

"Another plea for sparrows." 1868. Glasgow Herald, 12 September.

Argyll. 1884. "The unity of nature." Nature 29: 524-525.

Atran, S. 1990. Cognitive Foundations of Natural History: Towards Anthropology of Science. Cambridge: Cambridge University Press.

Barber, L. 1980. The Heyday of Natural History 1820-1870. London: Jonathan Cape.

Barrow, M .V. Jr 1998. A Passion for Birds: American Ornithology After Audubon. Princeton: Princeton University Press.

Becher, R. A. 1885. "Sparrows Feeding on Ants." The Zoologist 3: 259.

Bellon, R. 2001. "Joseph Dalton Hooker's ideals for a professional man of science." Journal of the History of Biology 34: 51-82.

2011. "Inspiration in the harness of daily labor: Darwin, botany, and the triumph of evolution, 1859-1868." Isis 102: 393-420.

Bircham, P. 2007. A History of Ornithology. London: HarperCollins Publishers.

Bowdler Sharpe, R. 1896. "Books on birds." Nature 54: 58-60.

Brodhead, M. J. 1971. "Elliot Coues and the Sparrow War." New England Quarterly 44: $420-433$.

Broks, P. 1996. Media Science before the Great War. London: Macmillan Press.

Burkhardt, R. W. Jr 2005. Patterns of Behavior: Konrad Lorenz, Niko Tinbergen, and the Founding of Ethology. Chicago: The University of Chicago Press.

Camerini, J. R. 1996. "Wallace in the Field." Osiris 11: 44-65.

Caron, J. A. 1988. "'Biology' in the Life Sciences: A Historiographical Contribution." History of Science 26: 223-268.

Cathcart, A. F. 1892. "Agriculturally economic ornithology." The Times, 16 May. 
Coates, P. A. 1998. Nature: Western Attitudes since Ancient Times. London: Polity. 2006. American Perceptions of Immigrant and Invasive Species: Strangers on the Land. Berkeley: University of California Press.

Collinge, W. E. 1913. The Food of Some British Wild Birds: A Study in Economic Ornithology. London: Dulau and Co.

Coues, E. 1885. "The English Sparrow in America." J. H. Gurney (ed.), The House Sparrow. London: William Wesley and Son, pp. 50-62.

Cowles, H. M. 2013. "A Victorian Extinction: Alfred Newton and the Evolution of Animal Protection." The British Journal for the History of Science 46: 695-714.

De Tschudi, F. (Ibbetson, H. L. B, Trans.). 1862. "Destructive Insects and the Immense Utility of Birds." The Journal of the Royal Agricultural Society of England 23: 231246.

Dearce, M. 2008. "Correspondence of Charles Darwin on James Torbitt's Project to Breed Blight-Resistant Potatoes." Archives of Natural History 35: 208-222.

"Destruction of small birds." 1862. The Times, 29 April.

"Destruction of sparrows." 1841. The Quarterly Journal of Agriculture 11: 432-434.

Di Gregorio, M. A. 2009. "Zoology." P. J. Bowler and J. V. Pickstone (eds.), The Cambridge History of Science: The Modern Biological and Earth Sciences, vol. Six. Cambridge: Cambridge University Press, pp. 205-224.

Dunlap, T. R. 1999. Nature and the English Diaspora: Environment and History in the United States, Canada, Australia and New Zealand. Cambridge: Cambridge University Press.

Evenden, M. D. 1995. "The Laborers of Nature: Economic Ornithology and the Role of Birds as Agents of Biological Pest Control in North American Agriculture, ca. 1880 1930." Forest \& Conservation History 39: 172-183.

Farber, P. L. 2000. Finding Order in Nature: The Naturalist Tradition from Linnaeus to E. O. Wilson. Baltimore: The John Hopkins University Press.

"Farmers and sparrows." 1867. The Essex Standard, and General Advertiser for the Eastern Counties, 25 December. 1897. The Morning Post, 15 April.

Finnegan, D. A. 2005. "Natural History Societies in Late Victorian Scotland and the Pursuit of Local Civic Science." The British Journal for the History of Science 38: 5372.

Gates, B. T. 1998. Kindred Nature: Victorian and Edwardian Women Embrace the Living World. Chicago: University of Chicago Press.

Goldsmith, O. 1816, c. 1774. A History of the Earth and Animated Nature. Volume One. London: Wingrave and Collingwood.

Gurney, J. H. 1885. The House Sparrow. London: William Wesley and Son.

Horn, P. 1984. Rural life in England in the First World War. New York: Gill and Macmillan.

Johnson, K. 2012. Ordering Life: Karl Jordan and the Naturalist Tradition. Baltimore: The John Hopkins University Press.

Lever, C. 1992. They Dined on Eland: The Story of the Acclimatisation Societies. London: Quiller Press.

Lovegrove, R. 2007. Silent Fields: The Long Decline of a Nation's Wildlife. Oxford: Oxford University Press.

MacDonald, D. G. F. 1865. "Our little birds." The Times, 11 October.

McNeill, J. R. 2003. "Observations on the nature and culture of environmental history." History and Theory 42: 5-43. 
Nelson, D. L. 2016. "The Ravages of Teredo: the Rise and Fall of Shipworm in US history, 1860-1940." Environmental History 21: 100-124.

Newman, C. 1861. "Destructive powers of sparrows." Nottinghamshire Guardian, 05 November.

Newton, A. 1899. A Dictionary of Birds. London: Adam and Charles Black.

Nunn J. P. 1897. "Yorkshire farmers and sparrows." The Times, 21 December.

Nyhart, L. K. 1996. "Natural history and the "new" biology." N. Jardine, J. A. Secord and E. C. Spary (eds.), Cultures of Natural History. Cambridge: Cambridge University Press, pp. 426-443.

2009. Modern Nature: The Rise of the Biological Perspective in Germany. Chicago: University of Chicago Press.

Ormerod, E. A. and Tegetmeier, W. B. 1897-1998. "The house sparrow." Journal of the Royal Horticultural Society 21: 413-425.

Osborne, M. A. 2000. "Acclimatizing the World: A History of Pragmatic Colonial Science." Osiris 15: 135-151.

Outram, D. 1996. "New Spaces in Natural History." N. Jardine, J. A. Secord and E. C. Spary (eds.), Cultures of Natural History. Cambridge: Cambridge University Press, pp. 249-265.

Rehbock, P. F. 1983. The Philosophical Naturalists: Themes in Early Nineteenth-CenturyBritish Biology. Madison: University of Wisconsin Press.

Richardson, E. W. 1916. A Veteran Naturalist. London: Witherby \& Co.

Ritvo, H. 1987. The Animal Estate: The English and other Creatures in the Victorian Age. Cambridge: Harvard University Press.

— 2012. "Going Forth and Multiplying: Animal Acclimatization and Invasion." Environmental History 17: 404-414.

Romanes, G. J. 1884. “The Unity of Nature.” Nature 29: 474-478.

Russell, C. 1883. "Martins and Sparrows." Essex Field Club 3: 20-23.

— 1885. "The house sparrow: by a friend of the farmers." J. H. Gurney (ed.), The House Sparrow. London: William Wesley and Son, pp. 19-45.

Seebohm, H. 1883. A History of British Birds, vol. 1. London: RH Porter.

Seeley, J. and Skabelund, A. 2015. "Tigers - Real and Imagined-In Korea's Physical and Cultural Landscape." Environmental History 20: 475-503.

Seitz, J. 2007. "Three Hundred Years of House Sparrow (Passer domesticus) Persecution in Germany." Archives of Natural History 34: 307-317.

Sheail, J. 1976. "Land Improvement and Reclamation: The Experiences of the First World War in England and Wales." Agricultural History Review 24: 110-125.

"Sparrows and corn." 1884. The York Herald, 10 July.

"Sparrows and agricultural crops." 1885. Berrow's Worcester Journal, 22 August.

"Sparrows and the crops." 1885. Western Mail, 27 August.

Specht, J. 2016. "The Rise, Fall, and Rebirth of the Texas Longhorn: An Evolutionary History." Environmental History 21: 343-363.

Star, S. L. and Griesemer, J. R. 1989. "Institutional Ecology, 'Translations' and Boundary Objects: Amateurs and Professionals in Berkeley's Museum of Vertebrate Zoology, 1907-1939." Social Studies of Science 19: 387-420.

Strasser, B. J. 2010. "Laboratories, Museums, and the Comparative Perspective: Alan A. Boyden's Quest for Objectivity in Serological Taxonomy, 1924-1962." Historical Studies in the Natural Sciences 40: 149-182. 
Tegetmeier, W. B. 1899. The House Sparrow (The Avian Rat): In Relation to Agriculture and Gardening, with Practical Suggestions for Lessening its Numbers. London: Vinton \& Co.

"The destruction of sparrows." 1862. Jackson's Oxford Journal, 06 December.

"The farmers and the sparrows." 1889. Leicester Chronicle and the Leicestershire Mercury, 28 December.

"The house sparrow (the avian rat) in relation to agriculture and gardening with practical suggestions for lessening its numbers. By W. B. Tegetmeier, F. Z. S., \&c. Vinton \& Co." 1899. The Zoologist 3: 375.

"The increase and destructiveness of sparrows." 1884. The Ipswich Journal, 12 August.

"The sparrow in the United States." 1889. The Times, 29 October.

"The troubles of our friends in Australia." 1868. The Times, 02 December.

"The sparrow club." 1855. The Times, 20 December.

"The English sparrow." 1868. The Times, 13 August.

"The ubiquitous sparrow." 1889. Rural World, 07 September: 452.

"The poor sparrows." 1895. The Morning Post, 08 June.

Thomas, K. 1983. Man and the Natural World. London: Allen Lane.

Todd, K. 2012. Sparrow. London: Reaktion Books.

Wallace, R. (Ed.). 1904. Eleanor Ormerod, LL.D. Economic Entomologist. Auto-Biography and Correspondence. New York: E.P. Dutton and Company.

"Wholesale destruction of sparrows." 1855. Bell's Life in London and Sporting Chronicle, 02 December.

Willis, R. G. 1974. Man and Beast. London: Hart-Davis, MacGibbon.

Wilmot, S. 1985. The Business of Improvement: Agriculture and Scientific Culture in Britain, c. 1770-c.1870. Cheltenham: Institute of British Geographers.

Worster, D. 1985. Nature's Economy: A History of Ecological Ideas, 2nd ed. Cambridge: Cambridge University Press.

Yarrel, W. 1843. A History of British Birds, vol. 1. London: John Van Voorst.

"Yorkshire farmers and sparrows." 1896. The Times, 08 December. 